UDC 821.161.1-14.09 Mandel'štam O. È. https://doi.org/10.18485/ms_zmss.2021.99.14

\title{
Валерий Мерлин
}

Исторический архив Яд Вашем

merlinvster@gmail.com

\section{Valerij Merlin}

Yad Vashem Documents Archive

merlinvster@gmail.com

\section{МОЦАРТ-ШМОЦАРТ И ПРОЧИЙ МАНДЕЛЬШТАМ. СЕМАНТИЧЕСКИЙ ОРЕОЛ И ФОНЕТИЧЕСКИЙ ШУМ ${ }^{1}$}

\section{MOZART-SHMOZART AND ALL THAT MANDELSTAM. SEMANTIC HALO AND PHONETIC NOISE}

В статье рассмотрены фонетические константы 3-стопного анапеста и 4-стопного хорея в поздних стихах Мандельштама и в поэме Кибирова Сквозь прощальные слезы. В отличие от интертекстуального подхода семантический ореол размера определяется не как сумма его исторических окрасок, а как шумовой фон, на котором прорисовываются отдельные окраски. Поскольку шум имеет мультимодальную природу, размер трактуется как оральная машина и как орудие письма. Два модуса шума - гипер- и гипоартикуляция, крик и шепот, «чирканье» и «маранье» - соответствуют двум размерам, рассмотренным в статье.

Ключевые слова: семантический ореол размера, поэтическая фоника, Мандельштам, Кибиров.

This paper concerns the phonetic constants of 3-feet anapest and 4-feet trochee in Mandelstam's later verse and in Kibirov's poem Through the Tears of Farewell. In opposite to the intertextual approach, the semantic halo of the meter is regarded not as a total of historical hues, but as a background noise from which the hues arise. The noise being a multimodal phenomenon, the poetical meter is regarded as oral machine and scriptural device. Two modes of noise - hyper- and hypoarticulation, shout and whisper, inscribing and blurring traces - correspond to the two meters considered in the paper.

Key words: semantic halo of the meter, sound in verse, Mandelstam, Kibirov.

В работах К. Тарановского концепция семантического ореола складывалась параллельно «подтексту» (Ронен 2000: 420). В этой конфигурации стихотворный размер приобретает генетическую память. Подобно тому, как вирус переносит частицы ДНК от одной клетки к другой,

1 Благодарю Г. В. Векшина и М. В. Акимову за обсуждение этой статьи. 
пятистопный хорей заражает один текст семантикой другого текста (Тарановский 2000). Механизм заражения остается неясным, но вирус действует: ореол «семантики», окружающий интертекст, проецируется на метрику (Илюшин 1986, Гаспаров 2012, Лотман 1988, Шапир 1995). Концептуальный бренд Тарановского транслируется нераспакованным, и это отмечено в последнем обращении к теме (Trunin 2017).

М. Л. Гаспаров настаивал на том, что размер не имеет органической семантики: все семантические окраски размера - исторические. Семантический ореол он понимает как сумму окрасок (Гаспаров 1979: 284). Но ореол - это больше, чем сумма, и если размер обладает ореолом (1984: 105), то это органическое качество. Комментируя книгу Гаспарова, Ю. И. Левин определяет размер как «надъязыковой код... в принципе семантически пустой, который, однако, сразу же при рождении, или позже “беременеет" значением, что обычно обусловлено появлением образца“шедевра”» (Левин 2012: 405-406). Кавычки здесь вполне уместны. Без кавычек нельзя понять, каким образом метрическая схема беременеет от шедевра и становится означающим того, что она не обозначает. Термин заражается от метафоры и заряжается метафорой: вирусным агентом становится сама семантика.

Вирусы действительно существуют, но действие Вируса выходит далеко за рамки биологии. Вирус - гиперверие, объект, возникающий в зоне резонанса реального и виртуального (Ланд 2019: 268-269). В гиперверие не обязательно верить, но веру в объект нельзя вычесть из объекта. Резонанс возникает в каждом ритмическом событии, то есть в каждом тексте, но зона резонанса не ограничена ничем кроме самого резонанса. Если говорить о само́м семантическом ореоле, не вычисляя его окрасок и оттенков, то это и есть пространство вибраций, не привязанное к текстам. Семантический ореол не складывается из окрасок. Наоборот, окраски вырастают из ореола. Не окраски расцвечивают радугу, а радуга играет окрасками. Резонанс создает зоны устойчивости, но эти зоны подвижны, и они возникают за счет нарушения внутренних связностей. Аналогией может служить нейронный щум как субстрат динамических паттернов, тем более, что две машины - метр и мозг - работают согласованно.

В пространстве резонанса интерпретация текста неотделима от самого текста. Семантический ореол включает в себя сам «семантический ореол» — в виде «облака смыслов», «ритмического гула», «музыки стиха». Эти метафоры резонируют в самом стихе, и значит мы имеем дело не с музыкой, а с шумом как пространством концептуальной интеграции (Fauconnier 2003). Вещество резонанса - звук, субстанция, меняющий свою форму в самом акте звучания. Существует акустичесая среда, окружающая объекты и тела, и эта среда виральна (Bennett 2009). «Звуки отвязываются от объектов или сознаний, получая сущностную автономию - они выступают переносчиками возмущений и значений, пересе- 
кающими тела» (Сафонов 2019). Вирусная трансдукция - двойная метафора, пришедшая в sound studies из computer science. Вирус пересекает границы логоса. Шумы резонируют.

В начале 1930-х годов в метрическом репертуаре Мандельштама резко возрастает доля анапеста (Плунгян 2011: 348). Взрыв начинается c «Гремучей доблести», из которой выделяются по крайней мере четыре текста - «Нет, не спрятаться мне от великой муры», Неправда», «Сохрани мою речь навсегда» и «Средь народного шума и спеха». Мы можем присутствовать при зарождении взрыва: черновые редакции стихотворения реконструированы И. Семенко (1997: 55).

Золотились чернила московской грязцы

И пыхтел грузовик у ворот

И по улицам шел на дворцы и морцы

Самопишущий черный народ.

2

$<$ пробел> шли труда чернецы

Как шкодливые дети вперед

Голубые песцы и дворцы и морцы

Лишь один кто-то властный поет:

3

За гремучую доблесть грядущих веков, За высокое племя людей, -

Я лишился и чаши на пире отцов

И веселья и чести своей.

Загадочное слово мориы И. Семенко возводит к «морить», но это скорее фонетический дублет слова двориы, образованный по типу шахер-махер и ёксель-моксель. Союз и обнажает семанику редупликации: «дворцы и все, что рифмуется с этим словом» то есть чепуха и всякая всячина. Стихотворение не бессмысленно. Бессмыслица - фонетический топос поэзии Манельштама тридцатых годов: «Нет, не спрятаться мне от великой мypы; О, лихорадка, о, злая моруха!; Перекипишь, а там, гляди, останется/Одна сумятииа и безработица».

В статье «Парные слова с начальным губным носовым» Вяч. Вс. Иванов связывает эту морфологическую модель с идиш (Иванов 2004), «и действительно, в большинстве случаев дело идет о еврейском (или, что в данном случае то же самое, антисемитском) пародийном либо просто шуточном словоупотреблении» (Лотман 2019: 652).

Редупликация активна в «Египетской марке» и в «Четвертой прозе»:

«Кому — Бурже, кому - Жорж Онэ, кому еще что-нибудь из библиотечного шурум-бурума» $(2,297)$; «Я китаец, никто меня не понимает. Халдыбалды! Поедем в Алма-Аmy, где ходят люди с изюмными глазами» $(2,350)$; 
«Был у меня покровитель — нарком Мравьян-Муравьян - муравьиный нарком из страны армянской - этой младшей сестры земли иудейской» $(2,351)^{2}$.

Китайщина - плохо прикрытый идишкейт. Mopus резонируют в «Жил Алксандр Герцевич» с отчетливой «иноэтнической окраской» и в «Я скажу тебе с последней прямотой»: оба стихотворения имеют ту же датировку, что и «Гремучая доблесть».

Ой ли, так ли, дуй ли, вей ли.

Все равно

Вряд ли здесь отражается немецкое Weh (Городецкий 2012: 344) скорее идишистское ой-вей и ой-ва-вой. На тот же ритм ложится пушкинская песня Мери, фокстрот и русская плясовая. Механизм редупликации - десемантизация. «Редупликат размывает значение редупликанта, делает его менее определенным» (Лотман 2017: 665). Семантика не может быть конструктивным принципом там, где скрещиваются языки.

Редупликация переходит в инерцию: дворизы - моризы - грязиьь $n e c u b l-$ - чернецы. В тот же ряд входит Москва - фонетический дуплет слова мезга, «кашицеобразная масса, получаемая при растирании, измельчении чего-л.» (Евгеньева 1999: 246): «Золотились чернила московской грязцы». Фонетический подтекст чернового наброска - само черновое письмо. «И когда я наполнился морем, Мором стала мне мера моя» $(1,240)$. Море сближается с мором как мера маранья.

Трехстопный трехсложник - авторезонансное устройство. Это касается всех трех размеров, но в анапесте резонанс законсервирован. Если считать, что ритмический паттерн развертывается от ядерного элемента к зависимому, т. е. от сильного слога к слабому, то анапест развертывается справа налево — из будущего в прошлое. Аvóл $\alpha 1 \sigma \tau о \varsigma$ — «отражённый назад»: размер развертывается, поскольку свертывается. Возвращаясь к самому себе, анапест пишет самого себя, но пишет лишь постольку, поскольку себя переписывает. «Мы только с голоса поймем, Что там царапалось, боролось» $(1,135)$. Чернь штурмует дворцы. Шкодливые дети заглушают учителя. Фонетика берет верх над семантикой, и семантика инскрибирует победу фонетики:

И пыхтел грузовик у ворот.

Ритмическая инерция строит гремучую машину, и поскольку машина постоянно застревает, она работает как машина письма: стихотворный размер строится как самопишущий коллективный черновик.

В бряцающих строках можно прочитать анаграмму слова «революция», но это прочтение вторично. Ключевое слово не рассеивается в тексте, а собирается из рассеяния. «Драматическая структура самого рас-

2 Тексты Мандельштама цитируются по (Мандельштам 2009). 
сказа вытекает из тембра, а вовсе не сам тембр подыскивается для нее и напяливается на нее, как на колодку» $(2,190)$. Внешний резонанс неотделим от внутреннего. Стих потому и бряцает, что резонирует сам с собой. Фонетическая память текста конструируется в самом тексте.

Стихотворение написано сигнатурным размером Надсона (Ан43), но семантически и фонетически здесь резонирует Блок:

Золотились иернила московской грязцы

И пыхтел грузовик у ворот...

За гремучую доблесть грядущих веков...

Не венчал мою голову траурный лавр

В эти годы пиров и скорбей.

Праздный слух был исполнен громами литавр,

Сердце - музыкой буйных страстей.

Возможно, один кто-то властный это и есть Блок. «Вся поэтика девятнадцатого века - вот границы могущества Блока, вот где он иарь, вот на чем крепнет его голос, когда его движения становятся властными, интонации повелительными» («А. Блок»). Но и Блок подчиняется чужому голосу: «Тяжелый трехдольник Некрасова был для него величав, как “Труды и дни” Гесиода. Семиструнная гитара, подруга Аполлона Григорьева, была для него не менее священна, нежели классическая лира» («А. Блок»). Гражданственный гекзаметр вырастает из жестокого романса. Двориь-мориьы - отзвук общеанапестического бряцанья.

Мне любить до могилы творцом суждено, Но по воле того же творца

Всё, что любит меня, то погибнуть должно, Иль как я же страдать до конца

(Лермонтов);

С бородою седою верховный я жреи,

На тебя возложу я душистый венеи,

И нетленною солью горячих речей

Я осыплю невинную роскошь кудрей;

(Фет)

У царицы моей есть высокий дворещ,

О семи он столбах золотых,

У царицы моей семигранный венец,

В нем без счету камней дорогих.

(В. Соловьев)

Как ты можешь летать и кружиться

Без любви, без души, без лица ?

О, стальная, бесстрастная птица,

Чем ты можешь прославить твориа ?

(Блок) 
Источник резонанса - скорее всего готическая акустика: «Но скажи наконец, кто ночной сей пришлец? ...Сей полуночный мрачный пришлец Был не властен прийти: он убит на пути Он в могилу зарыт, он мертвец» (Жуковский, «Замок Смальгольм»). По ходу скачки стук костей превращается в звон гитары и гром литавр.

Фонетическая формула анапеста транслируется самим анапестом:

Надрывается сердце от муки, Плохо верится в силу добра, Внемля в мире царящие звуки Барабанов, цепей, топора.

\section{(Н. Некрасов)}

Не в терновом венце, не под гнетом цепей,

Не с крестом на согбенных плечах, -

В мир придет она в силе и славе своей,

С ярким светочем счастья в руках.

(Надсон)

Бряцают цЕПи анаПЕста:

Анапест же... Он в души бойцов

Западет глубоко и надолго.

В самой нежности властно-суров,

Весь он дышит сознанием долга.

$$
\text { (П. Якубович) }
$$

Пастернак прячет анапестический романс внутри драматического александрийца:

Наследственность и смерть - застольцы наших трапез.

И тихой зарей, — верхи дерев горят -

В сухарнице, как мышь, копается анапест,

И Золушка, спеша, меняет свой наряд.

Мышь копается в сухарнице: анАПпест царАПается. Золушка меняет наряд, но роняет хрустальную туфельку:

Я живу $\boldsymbol{c}$ твоей карточкой, $\boldsymbol{c}$ той, что хохочет,

У которой суставы в запястьях хрустят,

Той, что пальцы ломает и бросить не хочет,

У которой гостят и гостят и грустят.

Хрустят суСТавы анапеСТа.

Для анапеста Некрасова характерно «конфликтное сочетание разнородных, противоборствующих элементов в пределах единого произведения» (Монахов 2005, 7). В песенном анапесте начала XX в. баллада сочетается с жестоким романсом (Фахретдинов 2012). Бряцанье как знак резонанса образует конструктивное поле семантики - фонетический 
ореол размера. Семантика конструируется под знаком резонанса при том, что в самом резонансе нет семантики. Мориы живут собственной жизнью.

Гремучая доблесть - субститут гражданской доблести, но смысл гражданственности - гремучесть. Инструмент резонанса — заздравная чаша. Поэт поднимает тост: Я пью за военные астры... за гремучую доблесть грядущих веков... за смолу кругового терпенья, за совестный деготь труда. Ангел Мэри, пей коктейли - отклик пушкинской здравицы: «Пью за здравие Мэри, бедной Мэри моей». Подымем стаканы звучит в Стихах о русской поэзии: Дай Языкову бутылку. И подвинь ему бокал и в Сталинской оде: Да будет жизнь крупна!. На этом фоне Дайте Тютчеву стрекозу, Догадайтесь почему - тоже застольный звон. Пир отцов празднуется в стихах самого поэта. Поэт - председатель этого пира. Заимствуя стихотворный размер отцов, сын лишается собственной чаши. Как это явствует из другого размера, рассмотренного в (Лейбов 2015): «Я пью за разоренный дом, За злую жизнь мою» (Ахматова); «За все, чем жили мы вчера, За все, что завтра ждем» (Исаковский); «Я пил из черепа отца За правду на земле» (Ю. Кузнецов).

Строка Фета «И нетленною солью горячих речей» цитируется в Шуме времени:

«Давно выкипели фетовские соловьи: чужая барская затея. Предмет зависти. Лирика. "Конный или пеший” - "Рояль был весь раскрыт" “И горящею солью нетленных речей”» $(2,254)$.

Стих цитируется неточно: в начало выносится фонетический ключ, как в строке Блока - «Не венчал мою голову траурный лавр» и как у самого Мандельштама: «За гремучую доблесть грядущих веков».

В статье о Пастернаке неточность акцентирована:

«Уходя, Фет сказал: “И горящею солью нетленных речей”. Эта горящая соль каких-то речей, этот посвист, щелканье, шелестение, сверкание, плеск, полнота звука, полнота жизни, половодье образов и чувств с неслыханной силой воспрянули в поэзии Пастернака. Перед нами значительное патриархальное явление русской поэзии Фета» $(2,144)$.

Смысл каких-то речей не имеет значенья. Цитата содержит пробел. Стихотворный размер строится как фонетический каркас с переменным семантическим заполненьем.

Пастернак - соловей-разбойник русской поэзии, «но не разбойничать нельзя» $(1,172)$. Чистое бряцанье - это пародия. Бряцает «школьная дразнилка» и «бурсацкая травля» $(2,191)$ :

Украшался отборной собачиной

Египтян государственный стыд, Мертвецов наделял всякой всячиной И торчит пустячком пирамид 
Сочинитель, щегленок, студентик, студент, бубенец...

Конькобежец и первенец, веком гонимый взашей.

Бубенцы звенят на колпаке юродивого. Тем же звуком он дразнит сурового Данта:

«Тридцать вторая песнь по темпу - современное скерцо... Выдергиваю на выбор одну только ниточку: "cagnazzi” - "riprezzo" - "quazzi" “mezzo”- “gravezza”. Щипки, причмокиванья и губные взрывы не прекращаются ни на одну секунду» (2, 190-191).

Фонетика юродства наглядна в «Четвертой прозе»: «В Доме $\boldsymbol{\Gamma} е р ц е-$ $\boldsymbol{\mu} \boldsymbol{a}$ один молочный вегетарианец - филолог с головенкой китайща... лицейская сволочь ... сторожит в специальном музее веревку удавленика Сережи Есенина. ... И всех посадить за стол в Доме Герцена, поставив перед каждым стакан полицейского чаю».

Бубенцы звучат и в сталинских куплетах:

А где хватит на полразговорца,

Там припомнят кремлевского горца.

Авторский комментарий — «Это будут петь комсомольщы на улицах» - подтверждает бряцанье.

Стихотворение начинается с метапоэтического зачина: Лишь один кто-то властный поет. Дальнейшее - цитата. Продолжением может быть любое анапестическое стихотворение Мандельштама - или не Мандельштама. Последняя строфа наброска подтверждает, что песня поется с чужого голоса:

Но услышав тот голос, пойду в топоры, Да и сам за него доскажу.

«Все, что я сейчас говорю, говорю не я» $(1,131)$. Все, что я говорю, есть продолжение песни. Но это значит, что вступление к песне не требуется. В пространстве авторезонанса текст и метатекст не различаются. Bce, что написано анапестом, есть самоописание анапеста.

По данным Р. Фахретдинова $(2018,138)$, в песенном анапесте начала XX в. самые частотные слова - жизнь (15), сердие (10) и могила (9). Судить о семантической окраске размера по этим предпочтениям трудно. Но если выписать слова, обладающие фонетическим сходством, семантика станет более определенной: горе, грудь, друг, кровь, враг, проклятье (31).

Песня идет в топоры:

Уж как пал туман на сине море,

А злодейка кручина в ретиво сердце. 
Не шуми, мати зеленая дубровушка...

Что заутра мне, доброму молодцу, во допрос идти

Перед грозного судью - самого царя.

(Соболевский 1895: 1,464; 6,332)

Фонетика ямщицкой и тюремной песни отразилась у Блока: «Тоска дорожная, железная Свистела, сердце разрывая; Когда звенит тоской острожнной Глухая песня ямщика». Мандельштам цитирует те же два жанра:

Я сжимаясь, гордился пространством за то, что росло на дрожжах; А за нами неслись большаки на ямщицких вожжах.

С нар приподнявшись на первый раздавшийся звук

Так вот бушлатник шершавую песню поет

В час, как полоской заря над острогом встает.

В Шуме времени Мандельштам говорит о власти звука над поколением отцов.

«Не смейтесь над надсоновщиной - это загадка русской культуры и в сущности непонятый ее звук... Как летние насекомые под накаленным ламповым стеклом, так все поколенье обугливалось и обжигалось на огне литературных праздников с гирляндами показательных роз, причем сборища носили характер культа и искупительной жертвы за поколенье» $(2,247)$.

Шум включает в себя баркаролы Рубинштейна, поэтический шурумбурум, шепелявую дикцию школьного учителя: «Чего он топорщцился перед детьми? ... Разбуженный, он топорщился), хрипоту революционных ораторов: «Революция - сама и жизнь и смерть...У нее пересохшее от жажды горло», барский окрик русской литературы: «Язык липнет к гортани. Стужа обжигает горло, и хозяйский окрик по столетию замерзает столбиком ртути».

Неназванный звук инскрибирован в тексте, и эта инскрипция имеет адрес.

Долго омрачали думы

Ямб, мыслительно-угрюмый,

Трубный, бранный анапест.

(С. Соловьев)

Трубный, бранный - или топорный. «Тяжелый трехдольник Некрасова был для него величав, как “Труды и дни” Гесиода». На литературных праздниках звучит тот же голос, который диктует стихи Блока. Поколенье приносит себя в жертву анапесту.

Разговор о Данте начинается с определения «орудийной метаморфозы»: 
«Поэтическая речь есть скрещенный процесс, и складывается она из двух звучаний: первое из этих звучаний — это слышимое и ощущаемое нами изменение самих орудий поэтической речи, возникающих на ходу в ее порыве; второе звучание есть собственно речь, то есть интонационная и фонетическая работа, выполняемая упомянутыми орудиями» $(2,155)$.

Поэтическая речь перформативна: это речь, которая «на полном ходу» конструирует свой язык. Орудийный порыв - это разрыв непрерывности: выход из континуальности речи в многомерное пространство языка. Орудие речи производится работой этого орудия. Топор рубит. Топор — грубый помощник строителя — «...и помощник мой грубый». Топор - антимузыкальное орудие, но это орудие обладает резонансом: при ударе топора лезвие звенит. Топор запирает: артикуляция прерывает поток голоса. Закупорка переходит в вибрацию, как в ямщицком тпрру: вибрирует само тело.

«И для казни петровской в лесах топорище найду». Голос зовет к топору, но топорность звучит в самой песне.

Мы только с голоса поймем,

Что там царапалось, боролось

И черствый грифель поведем

Туда, куда укажет голос.

(«Грифельная ода»)

В голосе звучит его неслышимое орудие — язык: голос инскрибирует работу этого орудия. Поэтические тексты Мандельштама — пространство метаязыковой записи: интерпретировать эти тексты - значит читать интерпретацию, которая в них заложена. Если в русском языке царапаются суффиксальные элементы («Вырви клавиш, и щучью косточку найдешь») и борются именные флексии («Бежит волна волной волне хребет ломая»), то грубая работа топора соответствует неоформленной корневой основе. «Обещаю построить такие дремучие срубы, Чтобы в них матарва опускала князей на бадье». Срубить избу это и значит ее построить. Конструкция языкового знака совпадает с его артикуляцией.

Для трехстопного анапеста характерна устойчивость словораздельных вариантов, из которых самый сильный падает после первой стопы. (Тарановский 2000; Монахов 2005). Фактически это цезура. Работа анапеста обозначена в самом анапесте: Аравийское месиво, крошево; Я ль без выбора ем это варево; Измеряй меня край, перекраивай. Работая своим орудием, поэт не оставляет себе другого выбора, кроме как перемалывать месиво и перекраивать крошево. При этом нельзя сказать, что он только раскручивает заверченное — «проецирует ось эквивалентности на ось последовательности». Скорее наоборот: возвращаясь к самой себе и проецируя саму себя, стих конструирует саму ось эквивалентности. Купированные части голоса звучат одновременно: песня превращается в шум, и поскольку резонирует морфология, это семантический шум. 
Термин древнеиндийской поэтики kriyā, обозначающий poetical work, соотносится с kártati, 'отрезать, рубить' и karjati 'мучать, причинять боль'. Кроме покроя поэтический текст обладает вкусом, rasā, родственным rasati, 'рычать, кричать, шуметь'. Kriya - инскрипция метра. Rasa - аберрация записи, то есть шум, но аберрация неотделимая от самой инскрипции. Раса скорби (karuna) входит в число эмоций, доставляющих наслаждение (Гринцер 1996: 47). Анапест не символизирует страдание. Наоборот, страдание инскрибирует анапест, но поскольку схема крепка записью, инскрипция размера становится его сигнатурой.

В Надзирать и наказывать Фуко говорит о блеске казни: средневековая казнь - праздничное зрелище (Фуко 2015: 24-47). Блестящей машине Фуко соответствует холостая машина Делеза. Ее образец биотехнологическое устройство, описанное в рассказе Кафки «В исправительной колонии»: это машина, которая работает «только в сломанном состоянии, постоянно ломаясь» (Делез 2007: 362). Действие машины заключается в поломке. Надрывается сердие от муки. Голос прерывается в письме. Артикуляция как орудийная метаморфоза голоса — это тоже письмо. Метаморфоза обозначена в одном из вариантов зачина:

Не табачною кровью газета плюет

Не костяшками дева стучит

Человеческий жаркий искривленный рот

Негодует поет говорит

Топор - перекроенный рот, а рот — искривленный топор: работа машины конструирует саму машину. Орудие сборки коллективного тела - Большой Рот. Обозначены три типа социальных медиа и три органа власти - газета, пишущая машинка и рупор громкоговорителя центральная точка советского пространства. Радиоголос либо говорит, либо обличает вредителей, либо поет: «Там играют Шуберта в раструбы рупоров» $(1,175)$. В артикуляции рта узнаются необоримые кремлевские слова, но резонанс голоса делает его неотличимым от народного хора. Расширенная оральность конструируется в 3-стопном анапесте: размер это и есть сама оральная машина.

Харкающий и сквернословящий рот принадлежит революции. Барский окрик исходит из уст русской литературы. И то и другое - оральные артикуляции: Большой Рот сам конструирует себя и свою семантику. По своему устройству это человеческий рот, искривленный линией губ. Жаркий рот кривится горячей солью речей. Конструкция органа совпадает с его деформацией: «И неправдой искривлен мой рот» $(1,475)$.

Неправда - кривда. Искривление орудия - это и есть его работа. Отсюда вариант 4 строфы:

Но меня возвращает к стыду моему Твой грозящий искривленный рот. 
Поскольку губы говорящего - орудие коллективного труда, оккупированное письмом, этот орган становятся публичным местом. Стыд заключен в самой оральной метаморфозе, обнажающей свой порыв, свое либидо. «Сохрани мою речь навсегда за привкус несчастья и дыма». Речь говорящего бесстыдна, поскольку обнажает свое интимное содержание и поскольку обращена к самой речи: никакой другой адресат не может сохранить привкус речи - ее семантическую коннотацию и фонетический ореол. Проговаривая речь, говорящий берет на прикус некрасовский анапест.

По свидетельству мемуариста, Мандельштам был болен «психическим голодом». «Осип Эмильевич... обедал за троих, ужинал за четверых и поедал невероятное количество сладкого» (Ивнев 2008: 121). Более точным диагнозом был бы семантический голод. «Тут вскрывается новая связь - еда и речь. Постыдная речь обратима вспять, обращена назад к чавканью, укусу, бульканью - к жвачке» $(2,191)$. Проговаривающая себя речь превращает рот в машину смысла: поэт говорит с набитым ртом. Рот наполняется смыслом в той мере, в какой его артикулирует:

Аравийское месиво, крошево,

Свет размолотых в луч скоростей.

Артикуляция конструирует «смысловое целое» речи — говорящую голову:

Я ль без выбора ем это варево,

Свою голову ем под огнем.

Играй же на разрыв аорты

С кошачьей головой во рту.

Работа Большого Рта заключается в артикуляции самой артикуляции - в инскрипции своих артикуляций. Оральная машина - орудие аккумуляции и концентрации голосов. Большой Рот работает как рожок - инструмент барона Мюнхаузена, испробованный в двух стихотворениях 1935 года:

И Шуберта в шубе замерз талисман...

И стынет рожок почтальона.

Талисман Шуберта - шарманка. Конденсат музыки - шум.

$\mathrm{B}$ «Стихах о русской поэзии» ищут и находят цитаты из русских поэтов. При этом теряется из виду, что все четыре стихотворения цикла (включая «Дайте Тютчеву стрекозу») написаны 4-стопным хореем. Это стихи о хорее, и объединяет их фонетический ореол размера: «Зашумела, задрожала, Как смоковницы листва... Шум на шум как брат на брата, Полюбил я лес прекрасный, смешанный...Там фисташковые молкнут Го- 
лоса на молоке... Тычут шапагами шишиги... И всегда одышкой болен Фета жирный карандаш».

Жирный карандаш туширует звук. В шуме участвует и Пушкин «То по кровле обветшалой Вдруг соломой зашумит», и Тютчев «В душном воздухе молчанье...» и Баратынский — «Страшный глас людских скорбей Гласом бури заглушая». Цитаты сшиты без прошвы: хорей воплощает шум стихотворства $(1,175)$ - «злобное и веселое шипенье русских стихов» $(2,254)$. Имя Пушкина не названо, потому что Пушкин это и есть шумовое облако, которым питается русское стихотворство. Стихи начинаются с шума - «В заботы суетного света Он малодушно погружен» — и возвращаются в шум:

Бежит он, дикий и суровый,
И звуков и смятенья полн
На берега пустынных волн
В широкошумные дубровы.

Шум не противостоит музыке. Шум - это музыка в ее пространственном измерении. Орудийная метаморфоза вырастает из идеи Бергсона: жизненный порыв как акт дифференциации есть синхронное сочетание диахронных линий - превращение времени в пространство (Делез 2000: 171). Смесь шума и музыки - это тоже шум.

Какая роскошь в нищенском селеньи - Волосяная музыка воды!; Но, видит Бог, есть музыка над нами, Дрожит вокзал от пенья Аонид, И снова, паровозными свистками Разорванный, скрипичный воздух слит; Шумела мельница, и в песнях урагана Смеялся музыки голубоглазый хмель.

Шум - семантический ореол музыки: «И Шуберт на воде, и Моцарт в птичьем гаме» $(1,186)$. Моцарт и Шуберт обозначают два полюса шума - гипер- и гипоартикуляцию: резкость/ слитность, царапалось/ боролось, чертить / марать, чернила/карандаш, scribo/schreibe (Мерлин 2019: 68-69). В черновике читаются несколько слоев текста, но смысл текста в том и состоит, что слои читаются одновременно. «Черновики никогда не уничтожаются... сохранность черновика - закон сохранения энергетики произведения» $(2,175-176)$.

Шум понятый как энтропия - обратная сторона информации (Маlaspina 2018). Хаос настолько хаотичен, что содержит в себе порядок (Meillassoux 2008). Орудийная метаморфоза задает другую перспективу: смысл не только возникает из шума, но и генерирует шум. Поэтическая речь - динамическое поле возможностей. Структура строится и перестраивается вместе с движением дискурса:

«Надо перебежать через всю ширину реки, загроможденной подвижными и разноустремленными китайскими джонками, - так создается смысл поэтической речи» $(2,156-157)$. 
В технике подвижного контрапункта диссонанс возникает как сверхсложное сочетание голосов. Каждый момент полифонического развития - точка сборки самонесущей конструкции:

На лапы из воды поднялся материк -

Улитки рта наплыв и приближенье -

И бьет в глаза один атлантов миг

Под легкий наигрыш хвалы и удивленья.

Речь идет об органной музыке, но если собрать всю музыку в момент синхронного звучания, то получится шум. Это и есть точка, где музыка находится сейчас - современный контрапункт, включающий в себя «не только нынешнее актуальное состояние, но и всю историю возникновения и изменения»... Так можно поколебать само разделение на синтагматическое и парадигматическое - ведь оно основано на разделении “творчества" на “тексты”. А гипертекст и его версии не делится по линии синтагма и парадигма» (Филановский 2020: 151-152).

Голоса поэтов вырастают из шума и возвращаются в шум. «Это грозно. Вот уже четверть века, как я, мешая важное с пустяками, наплываю на русскую поэзию; но вскоре стихи мои с ней сольются и растворятся в ней, кое-что изменив в ее строении и составе» $(3,548)$. На дождевое облако наплывает грозовая туча. Шум резонирует с шумом: Шум на шум, как брат на брата. «Поэтические батареи разговаривают друг с другом перекидным огнем» $(2,140)$. Ушная раковина наползает на улитку рта: в состав русской поэзии вливаются стихи о русской поэзии.

В поэме Кибирова Сквозь прощяальные слезы комментаторы находят около двадцати цитат из Мандельштама (Лейбов 2019: 445). В поэму вмещаются коммунары и коммуналки, радиола и рио-рита, но при чем здесь Мандельштам - не самый советский поэт эпохи? Впрочем, может быть и самый советский: Попробуйте меня от века оторвать. В поэме звучит шум времени и работает машина времени - Ан3. В шуме машины различимы голоса Некрасова, Блока, Исаковского, но машину сконструировал тот, кто пустил ее на холостой ход, то есть обнажил устройство:

И пыхтел грузовик у ворот.

В том же режиме функционирует анапест у Кибирова:

Чо-то всё барахлит, не фурычит, Не стыкуется и дребезжит.

Функция холостой машины - производство чистой интенсивности. Голоса поэтов окрашивают размер лишь постольку, поскольку шум содержит все голоса. Каждый голос вырастает из шума и возвращается в шум, но поскольку поэт инскрибирует размер, которым пишет, он ста- 
новится его автором: здесь вколачивал гвозди Некрасов и топорщился Мандельштам. Работу топора продолжают карбид, хлорка, солярка, барахолка, воркутинская пурга и заскорузлые подмышки мундира.

Анапест барахлит и у Некрасова - Надрывается сердие от муки, но поскольку машина работает только в полусломанном состоянии, ее неисправность не воспринимается как поломка.

Советское пространство - область действия холостой машины.

Пахнет дело мое керосином,

Керосинкой, сторонкой родной,

Пахнет «Шипром», как бритый мужчина,

И как женщина, — «Красной Москвой».

Речь идет о запахе родины, но запах неотличим от звука. Если родина - ароматический ореол анапеста, то анапест — голос родины. Территория матери сочетается с орудием отца: орудие и территория наработаны.

В анапестическую поэму вставлена хореическая Интермедия. В отличие от анапеста, в хорее действие ограничено областью самого действия. Грамматически это дуратив, функционально - середина речи. Хореическая вставка начинается с цитаты из Гейне (Лейбов 2020: 341):

Смотрят замки, горы, долы

в глубь хрустальных рейнских вод.

Моцарт, Моцарт, друг веселый, под руку меня берет.

Цитируется «Лирическое интермецио». Моцарт - хореическое слово, так же как Мандельштам - анапестическое. Это имя размера, и поскольку хорей — это облако шума, Моцарт - общее имя: «Кажется, Глюк. А может, и Моцарт вообще» («Солнечное утро»). Все, что сказано о Моцарте («друг веселый», «дух беспечный», «опечалился слегка»), относится к хорею:

А хорей говорлив, как весной
Ручеек серебристый и зыбкий;
Как дитя, омрачится тоской
И опять озарится улыбкой

(П. Якубович)

Моцарт - фонетический инскрипт хорея, но это хорей, в который уже влились «СТихи о русской поэзии» - сумма хорея, где «гейнеобразное» сочетается с народной песней и советским маршем. Моцарт отзывается на zart и mein herz, но поскольку это общеее имя, фонетическая маркировка стирается, и точно так же, как чернильное перо Тютчева превращается в жирный карандаш Фета, Гейне сменяет Пушкин вообще. Черты письма тушируются. 
Там и холодно и страшно!

Там прекрасно! Там беда!

\section{Работает машина смешения:}

Машет, машет треуголкой, в золотом луче горя, И ему со Вшивой Горки помахал ушанкой я.

B pendant гаспаровскому закону облегчения стиха к концу строфы Кибиров оглушает строфу к концу текста. Работа размера приводит к накоплению шума: не облако проливается дождем, а дождь собирается в облако.

Подарок Моцарта — из тех же запасов:

Что ж, прощай. Но на прощанье на, возьми бурундука!

Тютчеву - стрекозу, Веневитинову — розу, Кибирову - бурундука, и вместе с бурундуком карбид, барахолку и воркутинскую пургу. Поэт получает в подарок барахлящий анапест и шум времени — долгоиграющую машину барона Мюнхгаузена.

\section{ЛИТЕРАТУРА}

Гаспаров Михаил. «Семантический ореол метра: (К семантике русского трехстопного ямба)». Лингвистика и поэтика. Москва: Наука, 1979: 282-308.

Гаспаров Михаил. Метр и смысл. Об одном из механизмов культурной памяти. Москва: Фортуна ЭЛ, 2012.

Городецкий Лев. Квантовые смыслы Мандельштама. Москва: Таргум, 2012.

Гринцер Павел. Становление литературной теории. Москва: РГГУ, 1996.

Делез Жиль, Гваттари Фликс. Капитализм и шизофрения. Екатеринбург: У-Фактория, 2007.

Делез Жиль. Критическая философия Канта: учение о способностях. Бергсонизм. Спиноза. Москва: ПЕР СЭ, 2000.

Евгеньева Анастасия (ред.). Словарь русского языка. В 4-х т. 4-е изд., стер. Москва: Русский язык - Полиграфресурсы, 1999.

Иванов Вячеслав Вс. «Парные слова с начальным губным носовым». Иванов Вячеслав Вс. Лингвистика третьего тысячелетия: вопросы к будущему. Москва: Языки славянской культуры, 2004: 142-143.

Ивнев Рюрик. «С Осипом Мандельштамом на Украине». Сохрани мою речь. Вып. 4/1. Москва: Мандельштамовское общество, 2008: 120-132.

Илюшин Александр. «Н. А. Добролюбов как мастер стиха». Вестник Московского университета. Серия 9: Филология 2 (1986): 21-27.

Карстенс Дельфи, Ланд Ник. «Введение в гиперверие». Логос 29/5 (2019).

Левин Юрий. «Послесловие. Семантический ореол метра с семиотической точки зрения». Гаспаров Михаил. Метр и смысл. Об одном из механизмов культурной памяти. Москва: Фортуна ЭЛ, 2012: 405-409.

Лейбов Роман, Лекманов Олег, Ступакова Елена. «Господь! Прости Советскому Союзу!»: Поэма Тимура Кибирова «Сквозь прощальные слезы». Опыт чтения. Москва: ОГИ, 2012. 
Лейбов Роман. «Гармонисты во стане русских воинов: кроссжанровые перекодировки и трансляция литературного канона». Русская литература 4 (2015): 153-165.

Лотман Михаил. «Русский стих: Семантика стихотворного метра в русской поэзии второй половины XIX века (А. А. Фет и Н. А. Некрасов)». Slowianska metryka porownawcza. 3: Semantyka form wierszowych. Wroclaw etc.: Ossolineum, 1988: 105-143.

Лотман Михаил. «Ёксель-моксель. ёлки-палки. (h)uina-muina и прочие штучки-дрючки». Зборник Матице српске за славистику (Verba volant, scripta manent. Фестшрифт к 50-летию Игоря Пильщикова) 92 (2017): 641-673.

Мандельштам Осип. Полное собрание сочинений. В 3 т. Москва: Прогресс - Плеяда, 2009-2011.

Мерлин Валерий. «Еще раз о “Грифельной оде”: верстка понимания и ковка ключей». Зборник матице српске за славистику 96 (2019): 49-80.

Монахов Сергей. «К проблеме семантизации ритма русских трехсложников (трехстопный анапест и дактиль)». Вестник СПбГУ. Язык и литература 4 (2005).

Плунгян Владимир. «Метрика Мандельштама: к анализу структуры и эволюции». Coхрани мою речь. Вып. 5. Москва: Издательство РГГУ, 2011: 338-365.

Ронен Омри. «Ф. Тарановский и “раскрытие подтекста” в филологии». Тарановский К. Ф. О поэзии и поэтике. Москва: Языки русской культуры, 2000: 420-432.

Сафонов Никита. «Вирусная трансдукция: К вопросу о технике звучащего». Новое литературное обозрение 4 (2019).

Семенко Ирина. Поэтика позднего Мандельштама. Москва: Мандельштамовское общество, 1997.

Соболевский Алексей. Великорусские народные песни. Т. 1-7. Санкт-Петербург: Б. и., 1895-1907.

Тарановский Кирилл. «О взаимоотношении стихотворного ритма и тематики». Тарановский Кирилл. О поэзии и поэтике. Москва: Языки русской культуры, 2000: $372-403$.

Фахретдинов Рустам. “"Русская марсельеза”: жестокий романс Петра Лаврова». Антропологический форум 36 (2018): 117-153.

Филановский Борис. Шмоцарт. Санкт-Петербург: Jaromir Hladik press, 2020.

Фуко Мишель. Надзирать и наказывать. Москва: Ад Маргинем, 2015.

Шапир Максим. «Versus vs Prosa (пространство-время поэтического текста)». Philologica 2/ 3-4 (1995): 7-47.

Fauconnier Gilles, Turner Mark. "Metaphor, Metonymy, and binding”. Dirven René, Pörings Ralf (ed.). Metaphor and metonymy in comparison and contrast. Berlin - New York: Mouton de Gruyter, 2003: 477-478.

Bennett David, Colebrook Claire. "The Sonorous, the Haptic and the Intense". New Formations 66 (2009): 68-81.

Malaspina Cecile. An Epistemology of Noise. London: Bloomsbury, 2018.

Meillassoux Quentin. After Finitude: An Essay on the Necessity of Contingency. New York: Continuum, 2008.

Trunin Mikhail. "Towards the Concept of Semantic Halo". Studia Metrica et Poetica 4/2 (2017): 41-66.

\section{LITERATURE}

Bennett David, Colebrook Claire. "The Sonorous, the Haptic and the Intense". New Formations 66 (2009): 68-81.

Delez Zhil', Gvattari Fliks. Kapitalizm i shizofreniya. Ekaterinburg: U-Faktoriya, 2007.

Delez Zhil'. Kriticheskaya filosofiya Kanta: uchenie o sposobnostyah. Bergsonizm. Spinoza. Moskva: PER SE, 2000.

Evgen'eva Anastasiya (red.). Slovar' russkogo yazyka. V 4-h t. 4-e izd., ster. Moskva: Russkij yazyk — Poligrafresursy, 1999. 
Fahretdinov Rustam. «"Russkaya marsel'eza”: zhestokij romans Petra Lavrova». Antropologicheskij forum 36 (2018): 117-153.

Fauconnier Gilles, Turner Mark. "Metaphor, Metonymy, and binding”. Dirven René, Pörings Ralf (ed.). Metaphor and metonymy in comparison and contrast. Berlin - New York: Mouton de Gruyter, 2003: 477-478.

Filanovskij Boris. Shmocart. Sankt-Peterburg: Jaromir Hladik press, 2020.

Fuko Mishel'. Nadzirat' i nakazyvat'. Moskva: Ad Marginem, 2015.

Gasparov Mihail. «Semanticheskij oreol metra: (K semantike russkogo trekhstopnogo yamba)». Lingvistika i poetika. Moskva: Nauka, 1979: 282-308.

Gasparov Mihail. Metr i smysl. Ob odnom iz mekhanizmov kul'turnoj pamyati. Moskva: Fortuna EL, 2012.

Gorodeckij Lev. Kvantovye smysly Mandel'shtama. Moskva: Targum, 2012.

Grincer Pavel. Stanovlenie literaturnoj teorii. Moskva: RGGU, 1996.

Ilyushin Aleksandr. «N. A. Dobrolyubov kak master stiha». Vestnik Moskovskogo universiteta. Seriya 9: Filologiya 2 (1986): 21-27.

Ivanov Vyacheslav Vs. «Parnye slova s nachal'nym gubnym nosovym». Ivanov Vyacheslav Vs. Lingvistika tret'ego tysyacheletiya: voprosy $k$ budushchemu. Moskva: Yazyki slavyanskoj kul'tury, 2004: 142-143.

Ivnev Ryurik. «S Osipom Mandel'shtamom na Ukraine». Sohrani moyu rech'. Vyp. 4/1. Moskva: Mandel'shtamovskoe obshchestvo, 2008: 120-132.

Karstens Del'fi, Land Nik. «Vvedenie v giperverie». Logos 29/5 (2019).

Lejbov Roman, Lekmanov Oleg, Stupakova Elena. «Gospod’! Prosti Sovetskomu Soyuzu!»: Poema Timura Kibirova «Skvoz’ proshchal'nye slezy». Opyt chteniya. Moskva: OGI, 2012.

Lejbov Roman. «Garmonisty vo stane russkih voinov: krosszhanrovye perekodirovki i translyaciya literaturnogo kanona». Russkaya literatura 4 (2015): 153-165.

Levin Yurij. «Posleslovie. Semanticheskij oreol metra s semioticheskoj tochki zreniya». Gasparov Mihail. Metr i smysl. Ob odnom iz mekhanizmov kul'turnoj pamyati. Moskva: Fortuna EL, 2012: 405-409.

Lotman Mihail. «Russkij stih: Semantika stihotvornogo metra v russkoj poezii vtoroj poloviny XIX veka (A. A. Fet i N. A. Nekrasov)». Slowianska metryka porownawcza. 3: Semantyka form wierszowych. Wroclaw etc.: Ossolineum, 1988: 105-143.

Lotman Mihail. «Yoksel'-moksel'. yolki-palki. (h)uina-muina i prochie shtuchki-dryuchki». Zbornik Matice srpske za slavistiku (Verba volant, scripta manent. Festshrift k 50-letiyu Igorya Pil'shchikova) 92 (2017): 641-673.

Malaspina Cecile. An Epistemology of Noise. London: Bloomsbury, 2018.

Mandel'shtam Osip. Polnoe sobranie sochinenij. V 3 t. Moskva: Progress — Pleyada, 20092011.

Meillassoux Quentin. After Finitude: An Essay on the Necessity of Contingency. New York: Continuum, 2008.

Merlin Valerij. «Eshche raz o "Grifel'noj ode": verstka ponimaniya i kovka klyuchej». Zbornik matice srpske za slavistiku 96 (2019): 49-80.

Monahov Sergej. «K probleme semantizacii ritma russkih trekhslozhnikov (trekhstopnyj anapest i daktil')». Vestnik SPbGU. Yazyk i literatura 4 (2005).

Plungyan Vladimir. «Metrika Mandel'shtama: k analizu struktury i evolyucii». Sohrani moyu rech'. Vyp. 5. Moskva: Izdatel'stvo RGGU, 2011: 338-365.

Ronen Omri. «F. Taranovskij i "raskrytie podteksta" v filologii». Taranovskij K. F. O poezii i poetike. Moskva: Yazyki russkoj kul'tury, 2000: 420-432.

Safonov Nikita. «Virusnaya transdukciya: K voprosu o tekhnike zvuchashchego». Novoe literaturnoe obozrenie 4 (2019).

Semenko Irina. Poetika pozdnego Mandel'shtama. Moskva: Mandl'shtamovskoe obshchestvo, 1997.

Shapir Maksim. «Versus vs Prosa (prostranstvo-vremya poeticheskogo teksta)». Philologica 2/ 3-4 (1995): 7-47.

Sobolevskij Aleksej. Velikorusskie narodnye pesni. T. 1-7. Sankt-Peterburg, 1895-1907. 
Taranovskij Kirill. «O vzaimootnoshenii stihotvornogo ritma i tematiki». Taranovskij Kirill. O poezii i poetike. Moskva: Yazyki russkoj kul'tury, 2000: 372-403.

Trunin Mikhail. "Towards the Concept of Semantic Halo". Studia Metrica et Poetica 4/2 (2017): 41-66.

\title{
Валериј Мерлин
}

\section{МОЦАРТ-ШМОЦАРТ И ДРУГИ МАНДЕЉШТАМ. СЕМАНТИЧКИ ОРЕОЛ И ФОНЕТСКА БУКА}

\begin{abstract}
Резиме
У чланку су размотрене фонетске константе тростопног анапеста и четворостопног хореја у познијим песмама Мандељштама, те у поеми Кибирова Кроз опроштајне cyзе. За разлику од интертекстуалног приступа, семантички ореол метра се не одређује као збир његових историјских обојености, већ као бучан тон, на ком се оцртавају засебне нијансе. Будући да је бука мултимодалне природе, метар се тумачи као орална машина и оруђе за писање. Два модуса буке - хипер - и хипоартикулација, крик и шапат, „цвркутање“ и „мрмљање“ - одговарају двама метрима, размотреним у чланку.
\end{abstract}

Кључне речи: семантички ореол метра, песничка фоника, Мандељштам, Кибиров. 